\title{
Phonetisches Zeichen Based Learning Method to Improve Students German Sprechfertigkeit Speaking Skills
}

\author{
Jujur Siahaan \\ \{jujursiahaan15@gmail.com\} \\ Department of Foreign Language Education German Language Education Study Program, Faculty of \\ Languages and Arts, Universitas Negeri Medan, Indonesia
}

\begin{abstract}
This study aimed to develop a Phonetisches Zeichen based learning method in order to improve the Sprechfertigkeit speaking skills of German language students in Semester II Academic Year 2020/2021. This study with a focus on phonetisches Zeichenbased learning method was a research and development that uses ADDIE development model. The development model involved five phases, namely analysis, design, development, implementation, and evaluation. The subjects of this study included 24 second semester students of German Language Study Program. Data collection was conducted with the use of method validation questionnaires by expert validators and students Sprechfertigkeit pre-test and post-test. The instruments used consisted of method validation sheets and test question sheets. The data analysis techniques used were the assessments of the method feasibility and the student learning outcomes. Phonetisches Zeichen is a sub-discipline of phonology that is designed to describe how to pronounce sound symbols, be it vowels, diphthongs and consonants in German. Each sound is clearly transcribed in phonetisches Zeichen in accordance with the International Phonetic Alphabet (IPA) system. Sprechfertigkeit speaking skills refers to a person's ability to articulate sound or word to express, state and convey thoughts, ideas and feelings so that they can easily be understood. Clear and effective communication can be achieved if the articulation of the spoken message is correct according to pronunciation rules. The rules for pronouncing German sounds are found in the International Phonetic Alphabet (IPA) system. The phonetic spelling, the IPA system of speech sounds, is used to pronounce the spoken language, i.e., its sounds (vowels, consonants) and its prosodic features (intonation, e.g., word and sentence accent) [2]. Based on the IPA system and the application of the phonetische Zeichen method, students will be more skilled in speaking German. The primary function of language is for interaction and communication [4]. If students are able to communicate well, this means that the main objective of the German Language Education study program curriculum to improve students' speaking skills has been achieved.
\end{abstract}

Keywords: Phonetisches Zeichen method, Sprechfertigkeit.

\section{Introduction}

As a foreign language that has distinctive sound and pronunciation difficulties and is motivated by the limited frequency of German lessons at the General High School level, it is a factor causing the low quality of German language skills possessed by students, especially in 
the early semester. From the author's experience (as a lecturer in the German Language Study Program, it was found that students experienced difficulties, especially in the Sprechfertigkeit 'speaking skill' course). This is due to the unique and foreign sounds of German vowels, consonants and diphthongs to pronounce (eg the 'sch' sound in Deutsch, the 'spr' sound in Sprache, the 'ch' sound in the word ich, the sound ' umlaut' in hören, üben, Sätze and the 'eu' sound in heute). These difficulties will be overcome through phonetisches Zeichen based on the Internationales Phonetisches Alphabet German pronunciation guideline (IPA). Through Zeichen's phonetisches, a clear transcription of how the German sounds are pronounced can lead students to not be shy or afraid of making mistakes in speaking German. Speaking skill is one of the most important skills of language skills in the curriculum which includes four aspects, namely, listening skills, writing skills, speaking skills and reading skills. Speaking is the ability to pronounce articulation sounds or words to express, state and convey thoughts, ideas and feelings [1]. So that speaking skill means a person's ability to communicate clearly so that it can be easily understood and understood by the listener. Speaking skills can be achieved if the articulation of the spoken message is correct according to the pronunciation criteria. If the pronunciation of 'Aussprache' is in accordance with the existing guidelines, the communication will run smoothly, where the listener can easily understand what is meant. Learning speaking skills is an effort to be able to speak well. Starting from the pronunciation of vowels, increasing to the form of meaningful speech. In this study, the material on Sprechfertigkeit 'speaking skills' became the focus of phonetisches Zeichen to be transcribed according to the correct Aussprache 'pronunciation' based on the German Internationales Phonetisches Alphabet (IPA). Zur Beschreibung der gesprochenen Sprache, d.h. seiner Laute (Vocal, Konsonanten) und seiner prosodischen Merkmale (Intonation, z.B. Wort und Satzakzent), bedient man sich der Lautschrift, des Zeichensystem IPA (Internationales Phonetisches Alphabet) [2]. The learning method is a method or procedure used in carrying out teaching and learning activities to facilitate the implementation of various learning activities in order to achieve predetermined goals. The learning method can be interpreted as a technique or a typical pattern that is mastered by educators to present subject matter to students both individually and in groups so that the subject matter can be absorbed, and understood. It can be concluded that the method is a way to implement the plans that have been prepared in the form of real and practical activities to achieve learning objectives. The success of a learning process is determined by how well students can master the material through a method. For this reason, this study was intended to transcribe phonetisches Zeichen sound symbols of German, both vowels, diphthongs and consonants in order to improve students' speaking skills. Examples of German sounds that have a distinctive Aussprache 'pronunciation' difficulty include:

\begin{tabular}{|c|c|}
\hline Deutsch & [ d oY t [ ] 'German language' \\
\hline die Sprache & [ d i: $\int \mathrm{p}$ r a ç e ] 'language' \\
\hline wohnen & [ v o ? n e n ] 'reside in' \\
\hline morgen & [m o y g ə n] 'tomorrow' \\
\hline über & [ $\mathrm{y}: \mathrm{b}$ в ] 'about' \\
\hline schreiben & [ $\int \mathrm{r}$ a I b e $n$ ] 'write' \\
\hline
\end{tabular}

The occurrence of language sounds generally begins with the process of pumping air from the lungs to the larynx in which there are vocal cords, so that the sounds of language are: vowels, diphthongs and consonants. German vowels according to the international phonetic alphabet (Internationales Phonetisches Alphabet) consist of: : [e, i, ü, u, a, , o, ö]. Parameters for determining vowels are determined by the state of the high and low position of the tongue, the moving parts of the tongue, the structure and shape of the lips. 


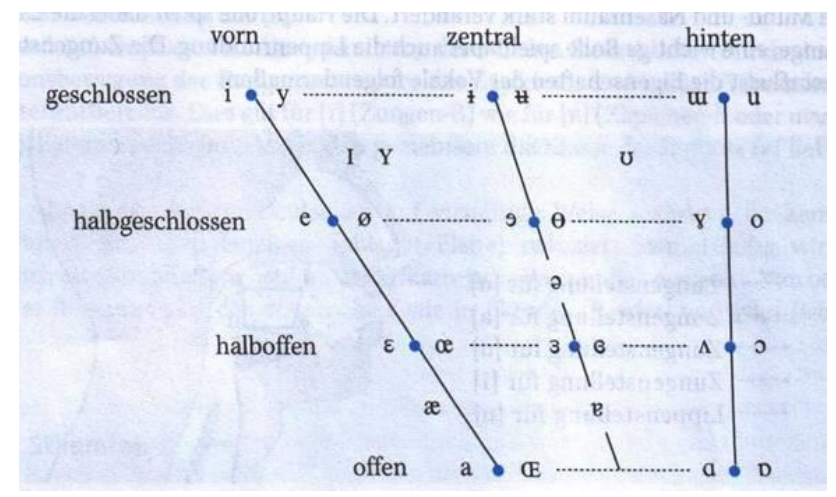

Fig. 1. Consonants.

Sounds are called consonants, when they are blocked at the articulator, accompanied by vibrating or non-vibrating vocal cords, so that consonants are formed, namely: bursting inhibitory consonants (stops, plosives) (bilabial: [p, b], apico-dental: [t , d], apico-alveolar: $[\mathrm{t}$, d], apico-palatal: [t, d], medio-palatal: [c, j] and dorso-velar: [k, g]), nasal consonants (nasal) (bilabial [m], apico - alveolar [n], medio-palatal [n̆] and dorso-velar [n]), apico-prepalatal (affricat) consonants [t], ], side consonants (laterals): [1 ], shifting or fricative consonants (labio - dental: [f, v], apico - dental:[e,], apico - palatal: [r], lamino - alveolar: [s, z], apico prepalatal: $[$,$] , dorso - velar: [\mathrm{x}]$ and laryngeal: $[\mathrm{h}]$ ), vibrating consonants (trills, vibrants) (apico-alveolar $[\mathrm{r}]$ and uvular $[\mathrm{R}]$ ). It is called diphthongs because the vocal cords do not produce two sounds, but one because they are in one syllable.
Example: die Zeitung
[d i: ts ae t u y] 'newspaper'
der Freund

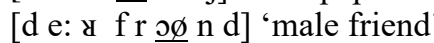
der Bauer

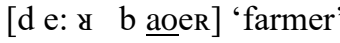
deutlich
[d oY t 1 I ç] 'clear'

Table 1. German vowels, diphthong, and consonant sounds.

\begin{tabular}{|c|c|c|}
\hline \multicolumn{3}{|c|}{ German Vowels and Diphthong Sound } \\
\hline Kurzvokale & Langvokale & Diphtonge \\
\hline was & Rat, Hahn, Aal & aI Hai, Ei \\
\hline$\epsilon \quad$ hell, Hände & e: den, sehr, See & au lau, (Kakao) \\
\hline I bin & i: $\quad$ Lid, ihr, sie & っY neu, Säue, (Boy) \\
\hline o dort & o: Rot, Ohr, Boot & uI pfui \\
\hline u um & u: $\quad$ gut, Uhr & \\
\hline ə bitte & $\epsilon$ : Bär, Ähre & \\
\hline (ə & ø: Öl, Höhle & \\
\hline œ Hölle & y: $\quad$ Tür, kühn, (Тур) & \\
\hline
\end{tabular}




\begin{tabular}{|ll|ll|}
\hline Y & Fünf, (Mystik) & & \\
\hline & & German Consonant & Sound \\
\hline b & bei, Ebbe & Schuh, (Chef) \\
d & du, Kladde & j & ja, (Voyeur) \\
g & geh, Egge & h & hier \\
p' & Pol, Nepp, ab & ç & (China), echt \\
t' $^{\prime}$ & Tat, satt, und (Theke) & x & acht \\
k' & Kuh, Bock, weg, quer, (Chor) & l lang, Ball \\
pf & Pfund & m & Mai, komm \\
ts & Zeit, Witz, (Cäsium) & n & nun, wenn \\
t & tschüss, Matsch & g & eng, Bank (=nk) \\
v & wer, (Vase) & r & rot, irre, (rh) - (Zungen-r) \\
f & Faß, vor, (Phase) & R & rot, irre, (rh) - (Zäpfchen-r) \\
z & so, Rose, (Gaze) & d & er, wir, Tor, für) \\
s & das, Masse, Maße & & \\
\hline
\end{tabular}

Table 2. Classification German consonant sound.

\begin{tabular}{|c|c|c|c|c|c|c|c|}
\hline \multirow[b]{2}{*}{ Artikulationsart } & \multicolumn{7}{|c|}{ Artikulationsstelle/-organ } \\
\hline & Bilabial & 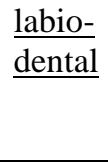 & $\begin{array}{l}\frac{\text { dental- }}{\text { alveolar }} \\
\text { (apikal/koro- } \\
\text { nal/dorsal) }\end{array}$ & $\frac{\text { Palatal }}{\text { (dorsal) }}$ & $\begin{array}{l}\frac{\text { Velar }}{\text { (post- }} \\
\text { dorsal) }\end{array}$ & $\underline{\text { Uvular }}$ & Glottal \\
\hline Öffnung & & & & & & & [h] \\
\hline \multirow{2}{*}{$\begin{array}{l}\text { Verschlu } \beta s t \\
\text { (Plosive) } s t l\end{array}$} & {$[\mathrm{~b}]$} & & [d] & & [g] & & \\
\hline & [p] & & {$[\mathrm{t}]$} & & {$[\mathrm{k}]$} & & \\
\hline \multirow{3}{*}{$\begin{array}{l}\text { Reibung,Enge sth } \\
\text { (Frikative) stl } \\
\text { (Lateral) sth }\end{array}$} & & [v] & [3] & [j] & [в] & & \\
\hline & & [f] & {$[\mathrm{s}]\left[\int\right]$} & [ç] & {$[\mathrm{x}]$} & & \\
\hline & & & [1] & & & & \\
\hline $\begin{array}{l}\text { Nasalöffnung } \\
\text { (Nasale) }\end{array}$ & {$[\mathrm{m}]$} & & [n] & & [n] & & \\
\hline $\begin{array}{l}\text { unter. Verschl. } \\
\text { (Vibranten) }\end{array}$ & & & {$[\mathrm{r}]$} & & & {$[R]$} & \\
\hline
\end{tabular}

Phonetics investigates how the sounds of language are produced by the organs (or "organs") of speech. The most commonly used phonetic writing system is the system of the Internationales Phonetisches Alphabet (IPA), which is marked with [ ]. 
In Zeichen's phonetisches 'phonetic transcription' each sound of a language is represented by the way in which it is pronounced. For example: phoneme "e" [e:, e, $\varepsilon, \varepsilon$ : dan ə ] [1 e b e n], [m o y g ə n], [e b ə n] dan [hern], phoneme “i” [i:, i, I] [Im], [ [li:ßen], [i:m] and [i:y], consonant [y, m, n] such us: [bedinuy], [flaye], [fayen], [tsaetuy], [hofnuy], Vibrant (Schwinglaut) [R, r] such us: [Riçtig], [e?Re], [beva?Ren], [auzRufen] and diphthongs [oY] [noY], [SoYe], [kakau], [aI]. If the pronunciation of 'Aussprache' is in accordance with the existing guidelines, then speaking skills can be achieved. For this reason, it is necessary to master the right articulation structure of speech.

\section{Method}

This type of research is research and development. The development of learning methods based on the Zeichen phonetisches method was developed using the ADDIE development model. The steps for developing this method are carried out based on five stages, namely analysis, design, development, implementation, and evaluation [3] and student learning outcomes using the before-after $\left(\mathrm{O}_{1} \mathrm{XO}_{2}\right)$ quantitative experimental design method.

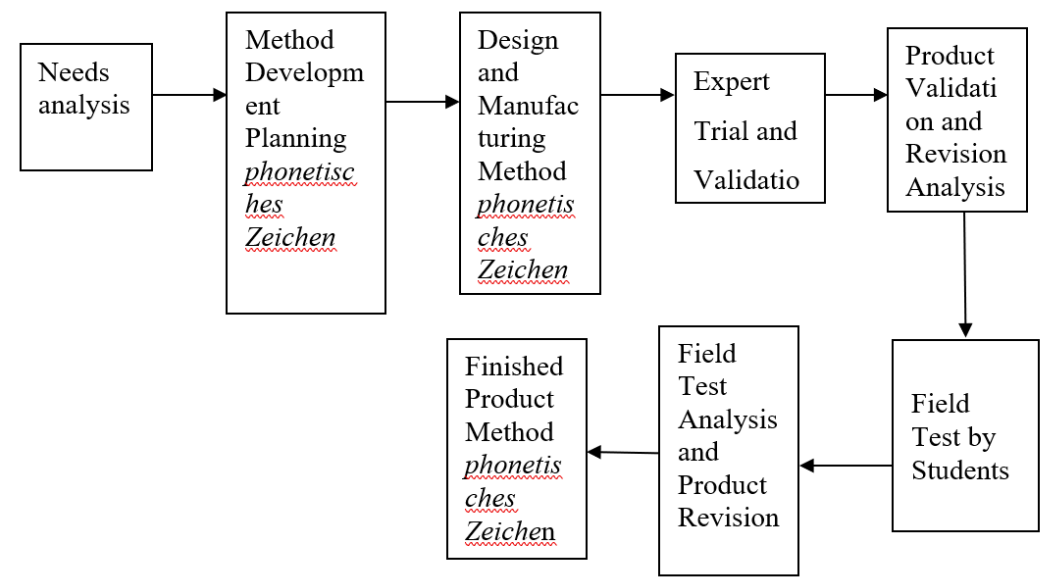

Fig. 2. Research method.

The test of the validity of the learning method is using expert validity according to the Likert scale with the criteria (1) very not good, (2) not good, (3) good, and (4) very good. This research was carried out at the Sprechen A2 lecture of the German Language Education Study Program, Department of Foreign Language Education, Faculty of Language and Arts, Medan State University, Academic Year 2020/2021. The research subjects were Semester II students of the Academic Year 2020/2021 who took the Sprechen A2 course as many as 24 second semester students. The product produced in this research is a learning method based on the Zeichen phonetisches method which will be used to improve speaking skills. The feasibility of the learning method by experts by providing responses with the criteria of very good, good, not good, and not good. The trial of the learning method was applied to the Sprechen A2 
lecture as well as the student's speaking skill test instrument to determine the effect of using the phonetisches Zeichen-based learning method to improve the mastery of Sprechen A2.

\section{Results and Discussion}

The stage of developing a learning method based on the Phonetisches Zeichen method in this study was adjusted to the rules or guidelines of the Internationales Phonetisches Alphabet (IPA). The purpose of developing this learning method is to improve students' ability in pronouncing and pronouncing each sound symbol, be it vowels, diphthongs and consonants in German, so that they are skilled in speaking, especially Sprechen A2. The results of developing a learning method based on the Zeichen phonetisches method are presented below.

[ferIen unt uylaub]

[ vilkommen Im RaIzəland doVt $\int$ land ]

[ fyy stadtuylaubər Ist haIdelberg Imməy aIn RaIzetsi:1] [vi:le toVristen kommen auz

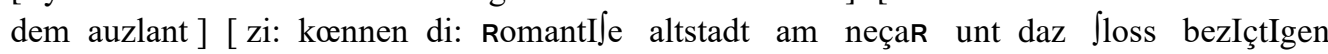
]

[ zommer, zonne, ]trand unt me:y - vi:le uylaubər maçen Im yulI unt auguz unt ferIen an de:y oztze:, tsum baezpi:1 auf de:y Inzel ry:gən] [ aInə tupI $\int \mathrm{doY} \mathbf{Y} \int \mathrm{e}$ tradItIon de:y $\int$ trandkorp ]

[ vi:le uylaubər entfaIden zIç f $\mathbf{Y}_{y}$ vInterferi:en unt fa:Ren tsum baezpi:1 In den thyrIner

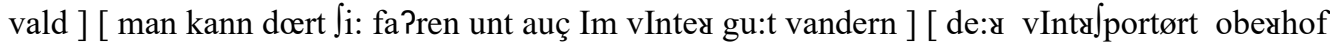
Ist InernatIonal bekannt ]

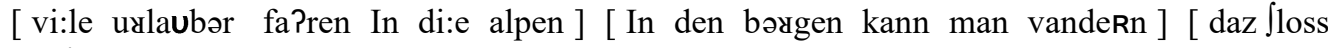

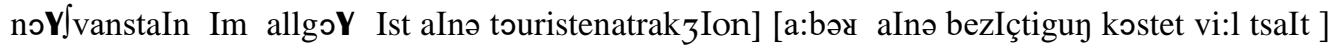

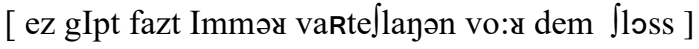

[ famillə meRtenz Im uylaub]

[ entlIç zommyferIən ]

[ eRzter tag noYnunttswantsigzten junI ] [ vo:ymIttags ankunft In pazzau ] [dort Paben vi:y faPrre:der gemi:tet] [ aInən raIzəfY?Rer Patten vi:y Jon] [ unzere radtoYr beginnt] [ di: eRzte etappe Izt kurts zi:benunttsvantsIg kIlometer ]

[ tsvaIter tag draIzigzten junI ] [ hoYte Paben vi: y aInuntzIbtsIg komma fynf kIlometer ge afft - von ejel?arztsell naç linz ] [ mIttags Paben vi:y aInekauft unt dann an de:y donau aIn piçniç gemaçt ] [ In linz Paben vi:y In aIner penzion y: bəunaçtet ]

[ maInə eltern varen se?y my:də]

[ drItter tag ersten julI ] [ hoYte Paben vi: y vi:dər den gantsen tag unervegz ]

[ vo:ymittagz Paben vi: y aInən bummel dV $\mathbf{r c ̧ ~ l i n z ~ g e m a c ̧ t ] ~ [ ~ I c ̧ ~ P a b e ~ l I n z e r ~ t o r t e ~ p r o b I e r t ~}$ se:y gu:t] [ mIttagz veIterfaPrt rIçtun melk] [dort Paben vi:y daz kloster besuçt]

[ zi:benter tag fynften julI ] [ naç draI?undert zeçs kIlometer ] [ vi:en ] [ daz ri:zenrat Im

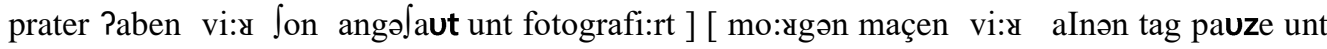
beziçtigen di: stadt ]

[ tsvantsigsten tag açtse?nten julI ] [zeçs?undertzeçstsig kIlometer ] [ vi: y Paben budapest erraIçt unt di: stadt beziçtigt ] [ di: toVr var toll unt vi: y Paben nette loYtə kenneneleRnt ] [ 
budapest Izt zuper ] [ laIdəu Izt de:y uylaub fazt tsu ende ] [ maI elteRn unt maInə Jvezter baIm pIçnIç ]

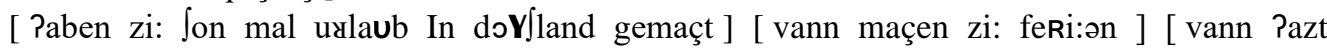
du gebuRtztag ] [ vann Izt de:y doV $\mathbf{k}$ kurz tsu endə ] [ vaz Izt daIn li:blinzmonat ]

[ daz vettəy va:R In den eRzten tagen gu:t] [ In marseille Pat ez aInen tag geregnet] [ Iç va:R mIt maInəm froønd tsvaI vəçen In zydfrạkraIç] [ main mann unt Iç va:Ren

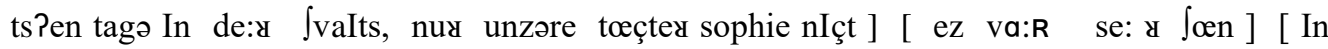
marseille va:r ez toll]

[ vo va:Ren zi: Im uylaub fRau abt] [ linz va:r zu:per ] [ vi: y va:Ren dort tsvaI tagə ] [ vi: y va:Ren In aInem Potel Im tsentrum y:bernaçtet] [ vi: y Paben aIne

[ Jiffzttour gemaçt unt den mariendom unt daz rathauz fotografi: ort ]

[ vi: y Paben di: altztadt ayefaut] [ unt vi: y Paben IIntser torte probi: ort ]

[ Pm ze: y leçer] [ daz va:R allez ]

The learning method based on the phonetisches Zeichen method that was developed received an assessment from a material validation expert, namely one of the lecturers from the German Education Study Program, Mrs. Linda Aruan, M.Hum. Validation was carried out in two stages until the learning method based on the Zeichen phonetisches method was declared valid and feasible to be tested. There are three aspects of the validator's scoring, namely the feasibility of content, language and the feasibility of presenting learning methods. The first stage of validation on the content feasibility aspect obtained an average score of 2.87 including quite valid criteria, the linguistic aspect obtained an average score of 2.85 including quite valid criteria, while the presentation feasibility aspect obtained an average score of 2.85 with quite valid criteria. The average number of all aspects of the feasibility of the material obtained a score of 2.86 which includes quite valid criteria. Based on the results of the validation of the feasibility of the material and language on the phonetisches Zeichen-based learning method, it is still necessary to make revisions according to the suggestions and input of the first stage of validation. The development of a learning method based on the phonetisches Zeichen method after being revised based on suggestions from validation experts, the next step is to carry out the second stage of validation. In the second stage of validation, each aspect gets an average score, the content feasibility aspect gets an average score of 3.78 with valid criteria, the linguistic aspect gets a value of 3.65 which is a valid criterion, and for the presentation feasibility aspect it gets a value of 3.60 which including valid criteria. The average value of each aspect is calculated as a whole related to the feasibility of the material and language, so that it gets an average score of 3.68 which is a valid criterion which means there is no improvement and can be used as a learning method. The score obtained from the second stage of validation is more advanced than the first stage of validation, so that the results of the feasibility of the material and language of the phonetisches Zeichen-based learning method are included in the "valid" criteria and deserve to be tested without revision. In the test of developing student learning outcomes in the Sprechen A2 course using a learning method based on the phonetisches Zeichen method, it was measured using the results of the pre-test and post-test of students at the initial meeting and the final meeting of the lecture. The average pre-test and post-test scores of the students' Sprechen A2 mastery can be seen in the following table: 
Table 3. Description of Student Sprechen A2 Mastery Score.

\begin{tabular}{lll}
\hline & Pre-test & Post-test \\
\hline N (Number of Students) & 24 & 24 \\
\hline Average & 62.5 & 87 \\
\hline Standard Deviation & 12.5 & 17.4 \\
\hline Maximum & 68 & 90 \\
\hline Minimum & 60 & 83 \\
\hline
\end{tabular}

The average score of students in the pre test was 62.5 while for the post test it was 87 . From these data it can be said that the increase in student learning outcomes on average increased by $24.5 \%$. The improvement is already "good enough". In the pre-test activity, more than $50 \%$ of students still got low scores. However, in the post-test activity, $80 \%$ of students were declared skilled in pronouncing each sound symbol, both vowels, diphthongs and German consonants according to the guidelines of the Internationales Phonetisches Alphabet (IPA). Although the increase was only $24.5 \%$, Sprechen A2 learning using the phonetisches Zeichen-based learning method could be categorized as "good enough".

\section{Conclusion}

Based on the validator's assessment, that the development of a learning method based on the phonetisches Zeichen method in Sprechen A2 in this study was in accordance with the criteria of education experts, so that the learning method based on the phonetisches Zeichen method was suitable for use in learning Sprechen A2. Based on the data analysis conducted, it can be concluded that the development of learning methods based on the phonetisches Zeichen method in the Sprechen A2 course can improve students' German speaking skills.

\section{References}

[1] Tarigan HG. Berbicara: Sebagai Suatu Keterampilan Berbahasa. Bandung: Angkasa; 2015.

[2] Kaunzner UA. Aussprachekurs Deutsch: ein komplettes bungsprogrammzur Verbesserung der Aussprache für Unterricht und Selbststudium. Heidelberg: Julius Groos Verlag; 1997.

[3] Sugiyono. Metode Penelitian Pendidikan Pendekatan Kuantitatif, Kualitatif, dan R\&D. Bandung: Alfabeta; 2013.

[4] Setiyadi BA. Teaching English as a Foreign Language. Yogyakarta: Penerbit Graha Ilmu; 2006. 